\title{
Should Colorectal Cancer Screening in Portugal Start at the Age of 45 Years? A Cost-Utility Analysis
}

\author{
Pedro Currais $^{a}$ Susana Mão de Ferro ${ }^{a}$ Miguel Areiab,c Inês Marques ${ }^{a}$ \\ Alexandra Mayer ${ }^{d}$ António Dias Pereira ${ }^{a}$ \\ ${ }^{a}$ Gastroenterology Department, Instituto Português de Oncologia de Lisboa Francisco Gentil, Lisbon, Portugal; \\ ${ }^{b}$ Gastroenterology Department, Portuguese Oncology Institute of Coimbra, Coimbra, Portugal; ${ }^{\circ}$ Center for Health \\ Technology and Services Research (CINTESIS), Faculty of Medicine of the University of Porto, Porto, Portugal; \\ ${ }^{\mathrm{d}}$ Registo Oncológico Regional, Lisbon, Portugal
}

\section{Keywords}

Colorectal cancer $\cdot$ Cancer screening $\cdot$ Cost analysis .

Colonoscopy $\cdot$ Occult blood

\section{Abstract}

Background and Objective: Colorectal cancer (CRC) is one of the most common cancers in Europe. Recently, new data from the USA and Europe revealed an increase in the incidence of CRC in individuals aged $<55$ years and a reduction in those aged $>65$ years. Mortality rate was stable in patients aged $<55$ years and decreased after the age of 55 years. Based on the USA data, the American Cancer Society (ACS) published a qualified recommendation advocating the start of CRC screening at the age of 45 years. We aimed to evaluate if the changes in the CRC incidence/mortality observed in the USA and the rest of Europe also occur in Portugal, and then perform a cost-utility analysis of CRC screening that starts at 45 years of age. Methods: We evaluated the incidence of CRC by age group using data from the National Cancer Registry, and the mortality rate according to the $\mathrm{Na}$ tional Statistics Institute in the periods 1993-2010 and 20032016. A cost-utility analysis was performed with a decision tree from a societal perspective comparing biennial fecal im-

karger@karger.com www.karger.com/pjg

Karger $\stackrel{\text { ' }}{5}$

GOPEN ACCESS
(C) 2021 Sociedade Portuguesa de Gastrenterologia Published by S. Karger AG, Basel

This is an Open Access article licensed under the Creative Commons Attribution-NonCommercial-4.0 International License (CC BY-NC) (http://www.karger.com/Services/OpenAccessLicense), applicable to the online version of the article only. Usage and distribution for commercial purposes requires written permission. munochemical test (FIT) or a single colonoscopy screening versus nonscreening at the age of 45 years in Portugal. $\boldsymbol{R e}$ sults: In Portugal, in 1993-2010, there was an increase in CRC incidence of $17 \%$ (from 25 to $30 / 100,000$ ), 35\% (from 39 to $54 / 100,000$ ), and $71 \%$ (from 52 to $97 / 100,000$ ) in patients aged $45-49$ years, $50-54$ years, and $55-59$ years, respectively. The mortality rate of patients aged $45-54$ years remained stable between 2003 and $2016(12 / 100,000)$ as a counterpoint to a moderate decrease in those aged 55-64 years (from 38 to $35 / 100,000$ ) and a sharp reduction in those aged 65-75 years (from 93 to $75 / 100,000$ ). Screening for CRC at the age of 45 years has no cost utility with the current incidence. FIT screening provided an ICUR of EUR 84,304/quality-adjusted life years (QALY) while colonoscopy provided an ICUR of EUR 3,112,244/QALY. On one-way sensitivity analysis, FIT screening would only have cost utility at the present cost of colonoscopy under sedation (EUR 150) and acceptance rates if the incidence rate rises above 47.5/100,000; colonoscopy at this age would have no cost utility despite changes in costs and/or incidence rates. Conclusion: In Portugal, the incidence of CRC in patients aged 45-55 years has been increasing with a stable mortality rate, in contrast to the decrease in mortality in the age groups covered by the current CRC screening program. However, at present, CRC screening 
in Portugal at the age of 45 years has no cost utility and will only have this if the incidence rate rises above $47.5 / 100,000$ (vs. the actual incidence of $30 / 100,000$ ).

(c) 2021 Sociedade Portuguesa de Gastrenterologia Published by S. Karger AG, Basel

\section{O rastreio do cancro colorretal em Portugal deve começar aos 45 anos? Análise de custo-utilidade}

\section{Palavras Chave}

Cancro colorretal · Rastreio oncológico · Análise

custo-eficácia · Colonoscopia · Sangue oculto

\section{Resumo}

Introdução e Objetivos: O cancro colorretal (CCR) é uma das neoplasias mais comuns na Europa. Recentemente, temos observado um aumento da incidência de cancro colorretal (CCR) em indivíduos $<50$ anos (não abrangidos pelos programas de rastreio), tanto na europa como nos Estados Unidos da América (EUA). Simultaneamente, a taxa de mortalidade (TM) permaneceu estável em doentes $<55$ anos e diminuiu $>55$ anos. Baseado nestes dados, a American Cancer Society (ACS) publicou uma recomendação qualificada advogando o início do rastreio aos 45 anos. Avaliar se as alterações na incidência/mortalidade de CCR observadas nos EUA/Europa também ocorrem em Portugal e realizar uma análise de custo-utilidade do início do rastreio de CCR aos 45 anos. Métodos: Avaliamos a incidência de CCR por faixa etária usando dados do Registro Oncológico Nacional (1993-2010) e TM de acordo com o Instituto Nacional de Estatística (20032016). A análise de custo-utilidade foi realizada com uma árvore de decisão sob uma perspetiva social, comparando o teste imunoquímico fecal bienal (FIT) com a realização de uma colonoscopia total aos 45 anos. Resultados: Em Portugal (1993-2010) observou-se um aumento na incidência de CRC de $17 \%$ (25/100.000 vs. $30 / 100.000)$, $35 \%(39 / 100.000$ vs. $54 / 100.000)$ e $71 \%$ (52/100.000 vs. 97/100.000) em doentes com 45-49 anos, 50-54 anos e 55-59 anos, respetivamente. A TM de indivíduos com 4554 anos permaneceu estável $(12 / 100.000)$ ao contrário da diminuição moderada em indivíduos com 55-64 (38/100.000 vs. $35 / 100.000)$ e uma acentuada redução em $65-75$ (93/100.000 vs. $75 / 100.000)$. O rastreio de CCR aos 45 anos não teve custo-utilidade na presente incidência (FIT/colonoscopia total). O rastreio com FIT forneceu um RCEl de $€$ 84.304/QALY, enquanto a colonoscopia forneceu um RCEI de $€$ 3.112.244/QALY. Em análise de sen- sibilidade unilateral, o rastreio com FIT apresentaria custo-utilidade com o custo atual da colonoscopia sob sedação $(€ 150)$ e taxas de aceitação apenas se a incidência subir acima de 47,5/100.000; o rastreio com colonoscopia nesta idade nunca teria custo-utilidade, apesar das mudanças nos custos e/ou taxas de incidência. Conclusão: Em Portugal, a incidência de CCR em doentes com idades entre 45-55 anos tem aumentado (TM estável). Este cenário é semelhante ao descrito nos EUA/restante europa. No entanto, o início do rastreio do CCR aos 45 anos em Portugal apenas terá custo-utilidade se incidência for $>47.5 / 100.000$ (vs. 30/100.000).

(C) 2021 Sociedade Portuguesa de Gastrenterologia Publicado por S. Karger AG, Basel

\section{Background and Objectives}

Colorectal cancer (CRC) is the second cause of cancer mortality in Europe and the first in Portugal, representing nearly $16 \%$ of all cancer-related deaths [1]. The overall incidence of CRC has increased in most European countries over the last 10 years. The annual increase ranges across different European countries, from 0.4 to 3.6\% [2]. However, it is expected that the recent introduction of CRC screening for individuals aged $\geq 50$ years will reverse this trend [2-4].

The CRC incidence has also risen in individuals $<50$ years of age, who are not included in most CRC screening programs $[5,6]$. The USA documented an increase in the incidence of CRC in individuals $<55$ years of age (45-49 years: $31 / 100,000 ; 50-54$ years: $58 / 100,000$ ), in contrast to a reduced incidence in those aged $>65$ years. The mortality rate was stable in patients aged $<55$ years ( $45-49$ years: $8 / 100,000 ; 50-54$ years: $13 / 100,000)$ and decreased in older patients. Based on this data, the American Cancer Society (ACS) showed that, in the US population, CRC screening beginning at the age of 45 years creates a favorable balance between screening benefits and burdens, thus supporting the recommendation for starting screening at 45 years [5]. A recently published analysis of CRC incidence and mortality rate in individuals aged $<50$ years in Europe (including a small region of northern Portugal) showed an increased incidence of $7.9 \%$ per year in individuals aged $20-29$ years (in 2004-2016), 4.9\% per year in those aged $30-39$ years (2005-2016), and $1.6 \%$ per year in those aged 40-49 years (2004-2016) [6]. The authors reported a large variability between countries and concluded that, if this trend continues, screening guidelines may need to be reconsidered; however, no formal recommen- 
dations were provided and no cost-effective analysis was performed [7].

In Portugal, there is still no universal screening program for CRC. Some geographical areas are covered by an organized screening program; in the remaining areas, opportunistic screening is performed in patients aged $>50$ years based on a biennial fecal immunochemical test (FIT), and a colonoscopy in cases with a positive FIT [8].

We aimed to evaluate changes in the CRC incidence/ mortality in patients in Portugal aged $<50$ years. We then performed a cost-utility analysis of CRC screening starting at 45 years of age, as no other countries outside the USA have produced data to support the ACS recommendations.

\section{Material and Methods}

\section{Study Population and Model}

A cost-utility analysis was performed using a decision tree model comparing 2 CRC screening strategies: a biennial FIT followed by colonoscopy if the FIT is positive $(\geq 100 \mathrm{ng} / \mathrm{mL}$ or 20 $\mu \mathrm{g} / \mathrm{g}$ ) or 1 colonoscopy, starting at the age of 45 years, versus nonscreening. The Portuguese population was considered in the model and a societal perspective was adopted, in accordance with recommendations for cost-effectiveness analysis reporting (including the costs to the healthcare system, patients, families, and employers [9].

\section{Data Source and Cost-Utility Analysis}

The decision tree intended to evaluate if starting a CRC screening program between the age of 45 and 50 years would have cost utility. This comes with the assumption that the CRC screening is already cost-effective for patients aged 50 years; screening starting at 50 years is already in place in some areas of Portugal, is the official policy of our Health Ministry, and was already proven to have cost utility in a previous study [10]. Data regarding the incidence of CRC by age group in the period 1993-2010 were taken from the Portuguese National Cancer Registry, and mortality rate data were collected according to the Portuguese National Statistics Institute for subjects aged 20-75 years in 2003-2016 [11, 12]. Incidence and mortality rates were expressed per 100,000 people. We used data from 2 different sources to be sure to obtain the most recent data available from both data sources (the National Cancer Registry and National Statistics Institute).

Clinical probabilities were obtained from an exhaustive literature review, and utilities were obtained from the literature providing values according to the disease location (colon vs. rectum) and stage (I/II/III/IV) [13, 14].

Costs were obtained from published tables of prices from the National Health Service and reported in euros for the year 2019, while the discount rate used was $3 \%$ according to published recommendations $[9,15]$. Efficacy was reported as utility using qualityadjusted life years (QALY). For the base-case scenario, the incidence rate used for the age group 45-50 years was 30/100,000, the FIT cost was EUR 3 with a 50\% acceptance rate, and the colonoscopy cost (colonoscopy under sedation) was EUR 150 with a 38\%

Colorectal Cancer Screening at 45 Years of Age?

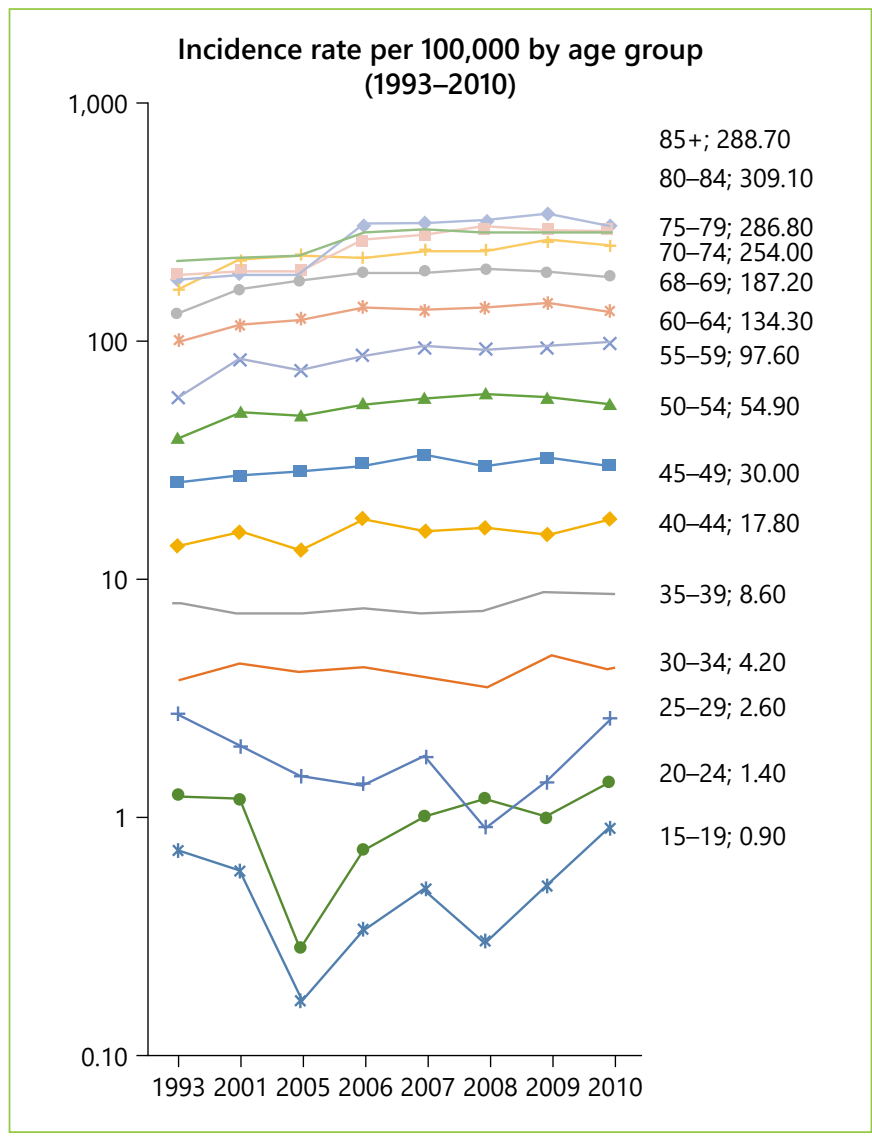

Fig. 1. Colorectal cancer incidence rate by age group between 1993 and 2010 in Portugal (data source: National Oncologic Registry).

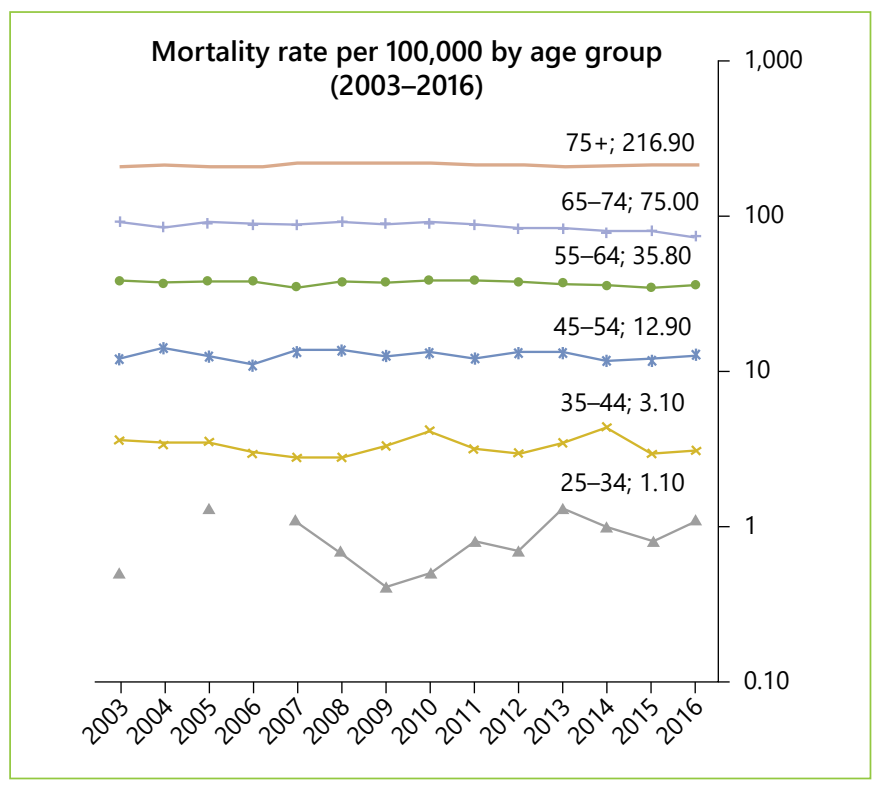

Fig. 2. Colorectal cancer mortality rate by age group between 2003 and 2016 in Portugal (data source: INE Statistics, Portugal). 


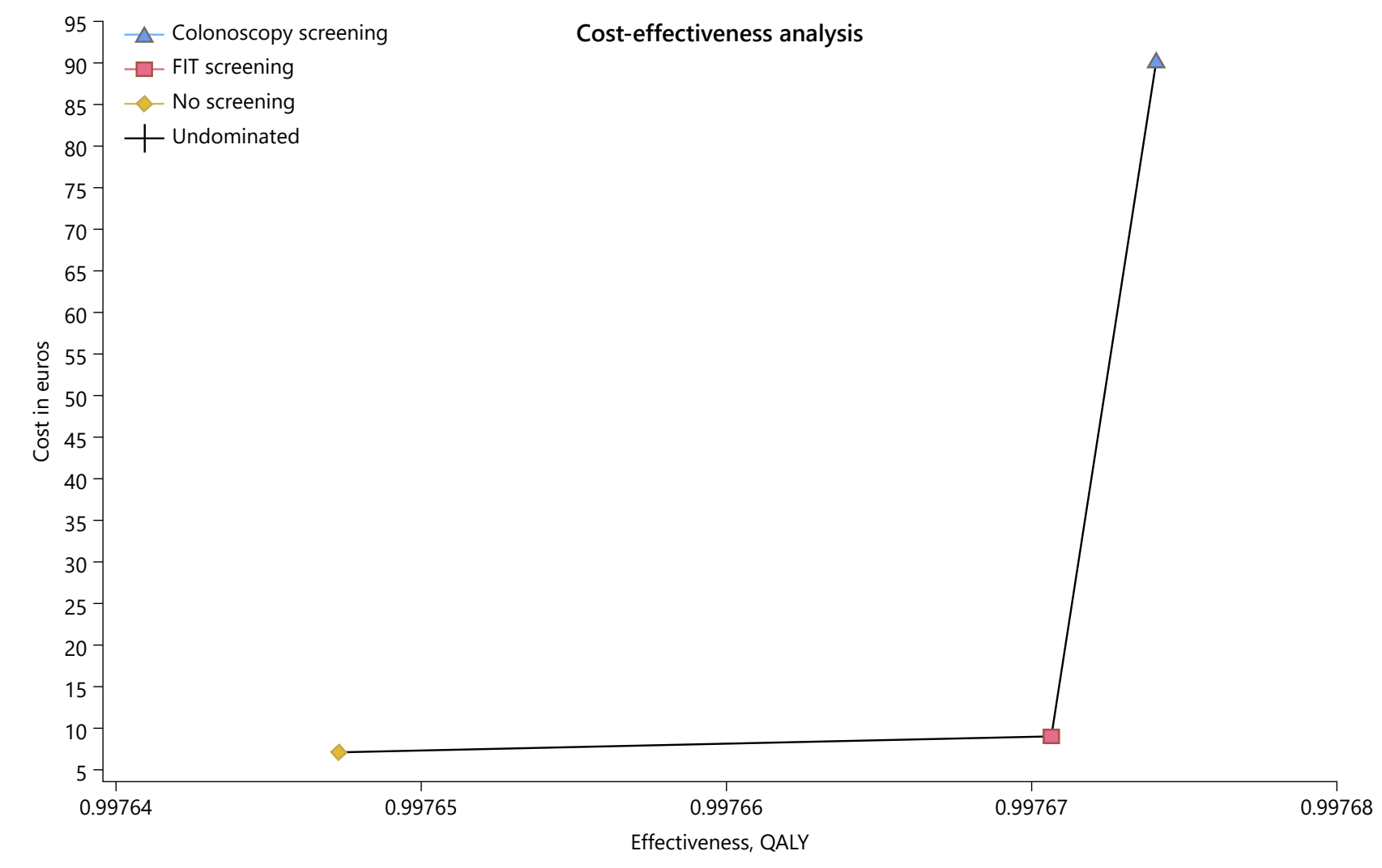

Fig. 3. Cost-utility analysis of fecal immunochemical test (FIT) or colonoscopy screening (EUR 150) versus no screening. $x$ axis represents the effectiveness in quality-adjusted life years (QALY). $y$ axis represents the cost in euros. The best screening strategy is
FIT, presenting a better combination of increased effectiveness and lower costs, providing an incremental cost-utility ratio of EUR 84.304/QALY (but above the threshold of EUR 39,760/QALY) versus EUR 3,112,244/QALY for colonoscopy.

Table 1. Cost-utility results for the base case scenario

\begin{tabular}{lllllll}
\hline Screening strategy & $\begin{array}{l}\text { Cost, } \\
\text { EUR }\end{array}$ & $\begin{array}{l}\text { Incremental } \\
\text { cost, EUR }\end{array}$ & Utility & $\begin{array}{l}\text { Incremental } \\
\text { utility }\end{array}$ & Cost utility & ICUR \\
\hline No screening & 7 & & 0.99765 QALY & & EUR 7/QALY & \\
FIT (EUR 150/colonoscopy) & 9 & 2 & 0.99767 QALY & 0.00002 QALY & EUR 9/QALY & EUR 84,304/QALY \\
Colonoscopy (EUR 150/screening) & 90 & 83 & 0.99768 QALY & 0.00003 QALY & EUR 90/QALY & EUR 3,112,244/QALY \\
FIT (EUR 397/colonoscopy) & 1 & 4 & 0.99767 QALY & 0.00002 QALY & EUR 11/QALY & EUR 176,213/QALY \\
Colonoscopy (EUR 397/screening) & 184 & 177 & 0.99768 QALY & 0.00003 QALY & EUR 185/QALY & EUR 6,620,987/QALY \\
\hline
\end{tabular}

FIT, fecal immunochemical test; QALY, quality-adjusted life years; ICUR, incremental cost-utility ratio.

acceptance rate. The outcome measure was the incremental costutility ratio (ICUR) between each of the screening strategies versus no screening, with costs in the numerator and effectiveness in the denominator. The threshold for the willingness-to-pay (WTP) was set at EUR 39,760/QALY ( $2 \times$ the gross national income per capita) and the primary outcome was the ICUR. The online supplementary Table (www.karger.com/doi/10.1159/000513592) provides the variables used in the model for transition probabilities and costs. 


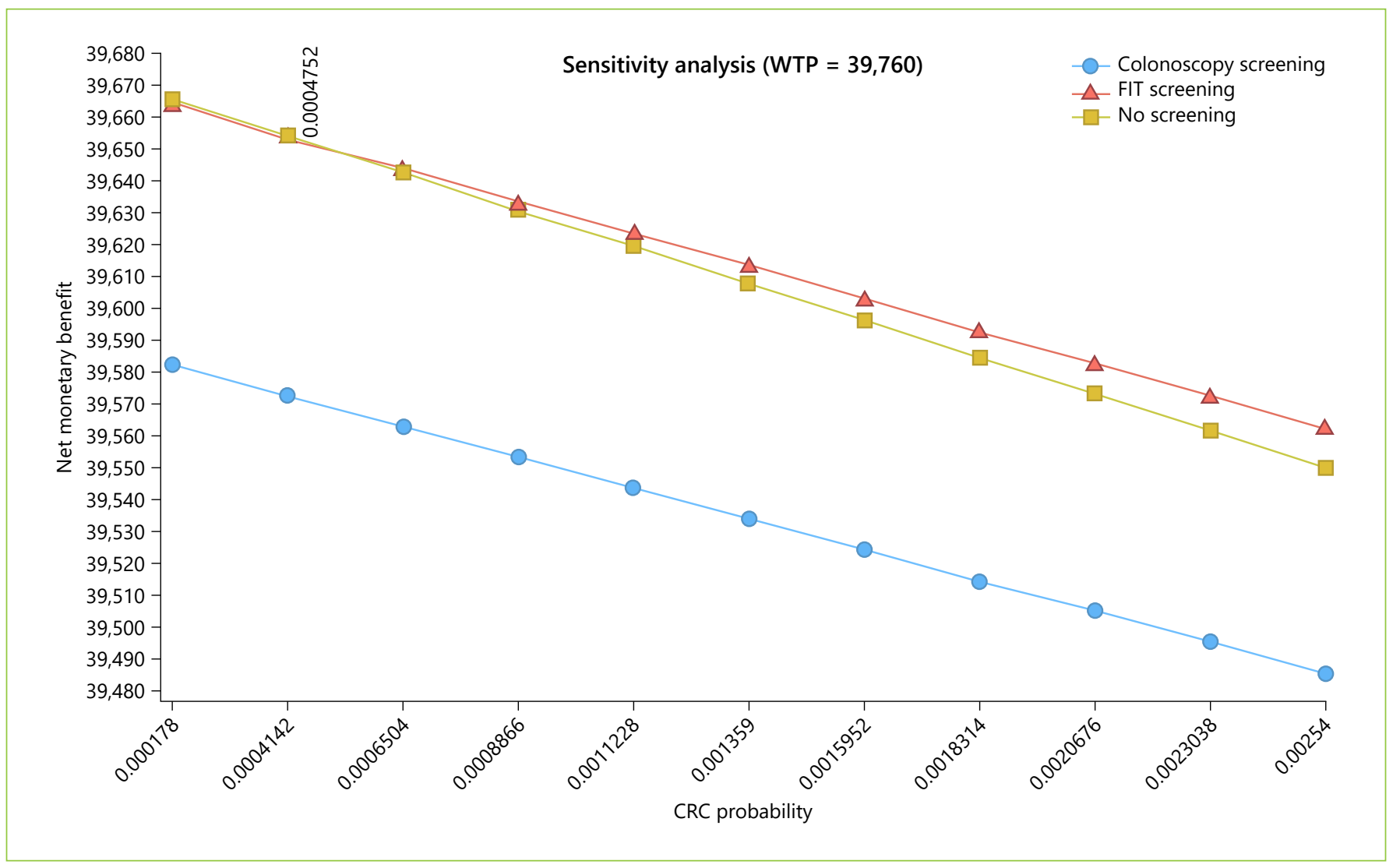

Fig. 4. One-way sensitivity analysis of the incidence of colorectal cancer (CRC; $X$ axis) influence on the incremental cost-utility ratio (ICUR; $Y$ axis). For a willingness-to-pay threshold (WTP) set at EUR 39,760/QALY, CRC incidence will have to rise up to

\section{Results}

In Portugal, in 1993-2010, there was an increase in CRC incidence of $17 \%$ (from 25 to $30 / 100,000$ ), $35 \%$ (from 39 to $54 / 100,000$ ), and $71 \%$ (from 52 to $97 / 100,000$ ) in patients aged $45-49$ years, 50-54 years, and 55-59 years, respectively. The mortality rate of patients aged 45-54 years remained stable between 2003 and 2016 $(12 / 100,000)$, as a counterpoint to a moderate decrease in those aged 55-64 years (from 38 to $35 / 100,000$ ) and a sharp reduction in those aged 65-75 years (from 93 to 75/100,000).

For those $<50$ years old, the incidence of colon cancer increased by $55 \%$ (from 4.5 to $7 / 100,000$ ) and the incidence of rectal cancer increased by $10 \%$ (from 3.9 to 4.3/100,000) (Fig. 1, 2).

According to our model, starting screening for CRC at the age of 45 years has no cost utility with the current in-

Colorectal Cancer Screening at 45 Years of Age?
47.5/100,000 for a fecal immunochemical test-based screening program to have cost utility starting at the age of 45 years (at a colonoscopy cost of EUR 150). Colonoscopy screening would never have cost utility.

cidence of $30 / 100,000$. When considering the current price of a colonoscopy with sedation, i.e., EUR 150, the strategy for a FIT screening provided an ICUR of EUR 84,304/QALY while the colonoscopy screening strategy provided an ICUR of EUR 3,112,244/QALY (the threshold was set at EUR 39,760/QALY). When considering the screening price of a colonoscopy with sedation, i.e., EUR 397 according to the Portuguese legislation for an organized screening program, the strategy for a FIT screening provided an ICUR of EUR 176,213/QALY while the colonoscopy screening strategy provided an ICUR of EUR 6,620,987/QALY (Table 1; Fig. 3).

In the one-way deterministic sensitivity analysis, and only considering the lower current cost of EUR 150 for colonoscopy with sedation, the option for a FIT screening would have cost utility at the present cost and acceptance rates if the CRC incidence rate rose above 47.5/100,000 (the current rates for people aged $\geq 50$ years, for whom 


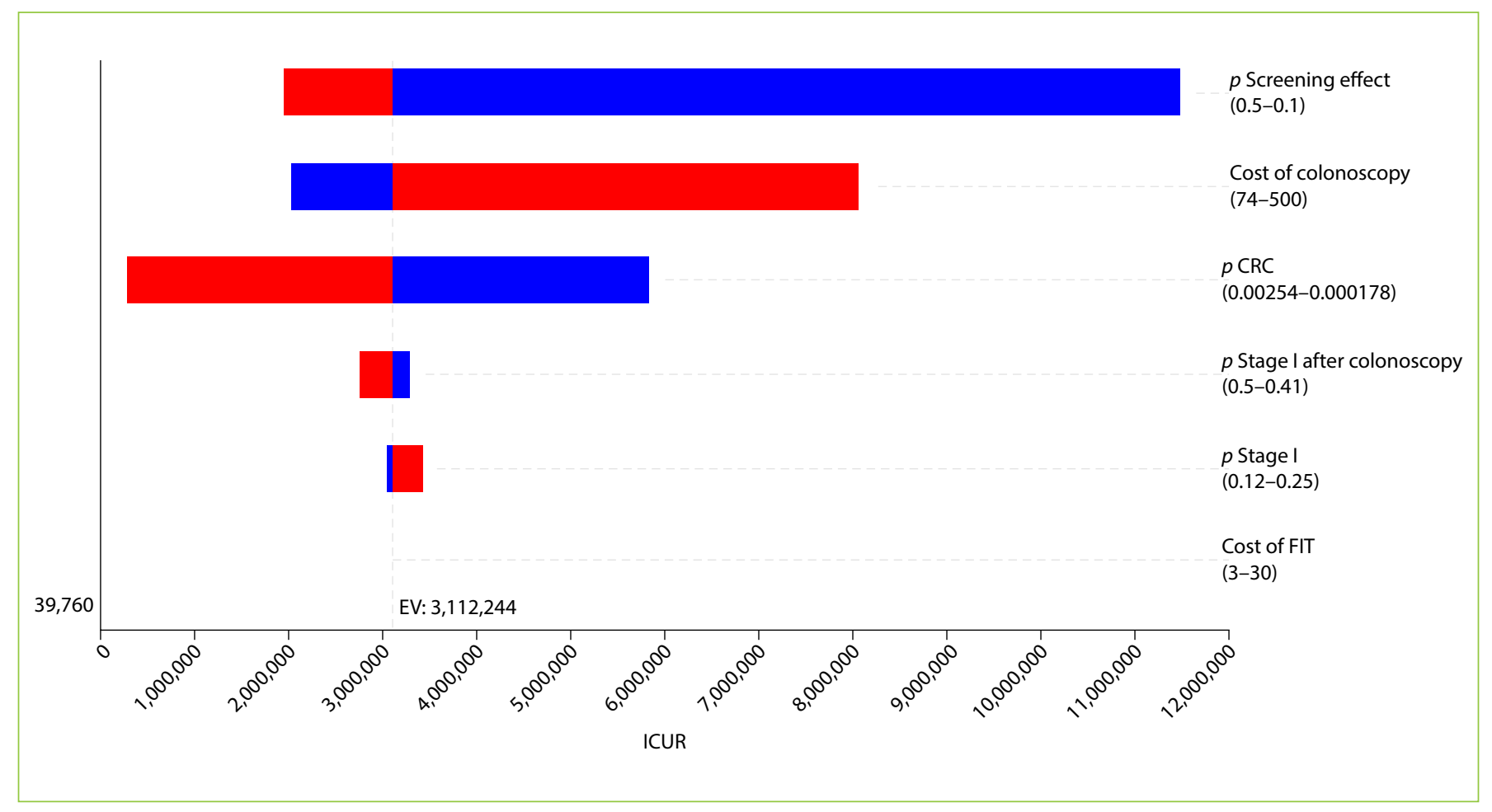

Fig. 5. Tornado diagram: deterministic sensitivity analysis of screening colonoscopy with sedation (EUR 150) versus no screening. Variables tested in one-way sensitivity analysis are displayed, while the $X$ axis represents the incremental cost-utility ratio (ICUR) for a willingness to pay EUR 39,790/QALY (dotted line on

screening is an accepted option) (Fig. 4); colonoscopy screening at this age, even at the current lower cost of EUR 150 per exam, would not have cost utility despite changes in costs and/or the incidence rate (Fig. 5). In the probabilistic sensitivity analysis, all 1,000 simulations of FIT screening versus no screening returned to above the threshold line, corresponding with the model result that, only on the very rare occasion that the CRC incidence would rise above 47.5/100,000 would the screening have cost utility (Fig. 6).

\section{Discussion}

Our model showed an increased CRC incidence in individuals $<55$ years of age in Portugal, mainly due to the increased incidence of colon cancer, as opposed to rectal cancer, but still not enough to render a screening program at this age to have cost utility. the left). Variables having the widest range for the result with a wider line are situated at the top. Variables are followed by the values of their range considered in the analysis. Variables not displayed were even less relevant for the model. CRC, colorectal cancer; FIT, fecal immunochemical test.

The etiology of this trend is yet unknown. This phenomenon has also been observed in other parts of the world such as other European countries, the USA, Australia, and China, and it may be caused by the adoption of a western lifestyle dominated by an excess of nutrients (and obesity associated with a chronic low-grade inflammatory response in metabolic cells), a lack of physical activity, alcohol consumption, and cigarette-smoking [6, 16-18]. These particular lifestyle factors have been associated mainly with colon cancer but not with rectal cancer $[19,20]$.

European guidelines recommend CRC screening starting at the age of 50 years [21]. We documented a 35 and $71 \%$ increase in CRC incidence in the age group 4549 years and 50-54 years, respectively. These data come hand-in-hand with a stable mortality rate in individuals 45-54 years of age, as a counterpoint to a significant decrease in older patients (affected by the CRC screening program).

Beginning screening earlier (at 45 years) would benefit these patients, not only for diagnosing CRC at earlier 


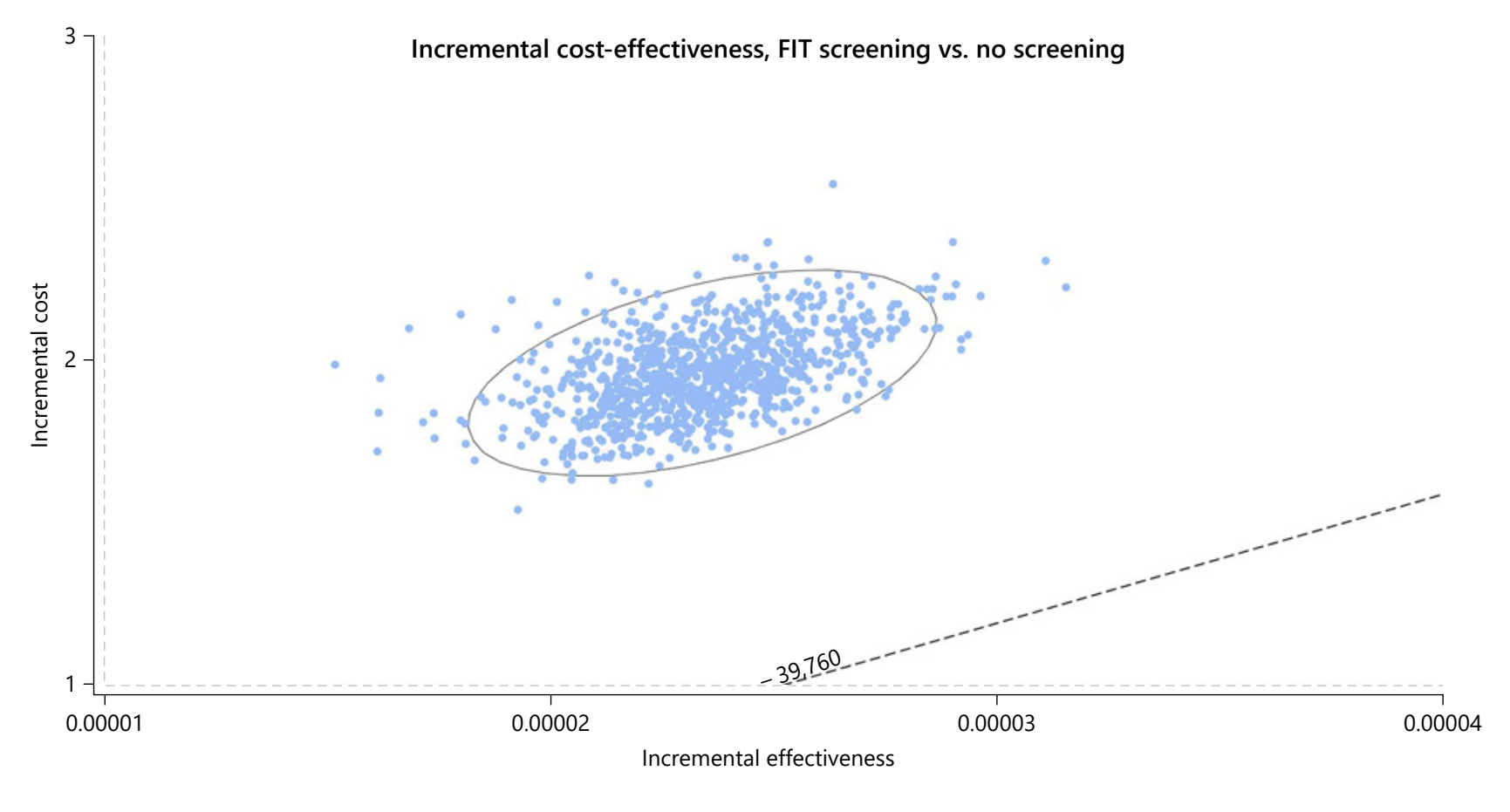

Fig. 6. Scatter-plot for probabilistic Monte Carlo sensitivity analysis of FIT screening versus no screening. Plot of 1,000 simulations where each dot represents 1 simulation. $X$ axis represents the incremental utility in terms of QALY and the $Y$ axis represents the incremental costs in euros. The ellipse surrounds the estimates that fall within the $95 \%$ confidence intervals. Cost-utility simulations should be situated below the dotted line representing the willingness-to-pay threshold set at EUR 39,760/QALY. FIT, fecal immunochemical test; QALY, quality-adjusted life years. stages but also allowing for the removal of large polys that would evolve in CRC in the near future (i.e., have a preventive effect on the individuals 50-54 years of age). In contrast, starting screening at age the age of 45 years has the major disadvantage of using valuable endoscopic resources that are needed to properly screen patients in the age group 50-75 years, who would benefit the most from screening.

The ACS analysis, however, showed a favorable benefit-to-burden balance, with an expected reduction in CRC incidence and mortality [5]. However, in Portugal, CRC screening at these younger ages had no cost utility with the present CRC incidence at the age of 45 years. The FIT screening would only have cost utility at its present cost and acceptance rates if the incidence rate rises above 47.5/100,000 (vs. the current incidence of just 30/100,000).

Several limitations of our study need to be addressed: not every hospital (mainly private hospitals) provided their data regarding CRC diagnosis to the National Can- cer Registry, so we probably underestimated the true CRC incidence in the Portuguese community. We could only obtain incidence data up to 2010 as no later data are yet available; this limited the analysis of more recent trends. Finally, the present model is applicable to the Portuguese population, but any comparisons regarding other populations must be made with caution due to different assumptions about CRC incidence and mortality, and obviously about costs.

Despite the results of our study providing arguments against starting a CRC screening program at 45 years in Portugal, it is important to monitor the increasing incidence of CRC and the clinical relevance at a younger age, to be able to assess whether screening practices need to be addressed in the near future. This work has highlighted the importance of having trustworthy and universal $\mathrm{Na}$ tional Cancer Registry data to evaluate these changes and act accordingly. 


\section{Conclusion}

In Portugal, the incidence of CRC in patients aged 4555 years has been increasing but remains at $<30 / 100,000$, despite a stable mortality rate, contrary to the decrease in mortality in the age groups covered by the current CRC screening programs. This scenario is similar to what has been described in the USA and in other European countries. Starting CRC screening in Portugal at the age of 45 years still has no cost utility at present. This may soon alter if the incidence rate rises to $47.5 / 100,000$.

\section{Statement of Ethics}

No ethics approval for this article was required since all the data used (from National Cancer Registry and National Statistics Institute) is information freely available in the public domain.

\section{Conflict of Interest Statement}

The authors have no conflicts of interest to declare.

\section{Funding Sources}

The authors received no financial support for the research, authorship, or publication of this article.

\section{Author Contributions}

S.M.F. and P.C.: conception of the study; P.C., I.M., A.M., S.M.F, and M.A.: data interpretation; P.C., S.M.F, and M.A.: statistical analysis and drafting of the manuscript; S.M.F. and A.D.P.: final critical revision.

\section{References}

1 Ferlay J, Steliarova-Foucher E, Lortet-Tieulent J, Rosso S, Coebergh JW, Comber H, et al. Cancer incidence and mortality patterns in Europe: estimates for 40 countries in 2012. Eur J Cancer. 2013 Apr;49(6):1374-403.

2 Arnold M, Sierra MS, Laversanne M, Soerjomataram I, Jemal A, Bray F. Global patterns and trends in colorectal cancer incidence and mortality. Gut. 2017 Apr;66(4):683-91.

3 Doubeni CA, Corley DA, Quinn VP, Jensen $\mathrm{CD}$, Zauber AG, Goodman M, et al. Effectiveness of screening colonoscopy in reducing the risk of death from right and left colon cancer: a large community-based study. Gut. 2018 Feb;67(2):291-8.

4 Rosato V, Bosetti C, Levi F, Polesel J, Zucchetto A, Negri E, et al. Risk factors for youngonset colorectal cancer. Cancer Causes Control. 2013 Feb;24(2):335-41.

5 Wolf AM, Fontham ET, Church TR, Flowers CR, Guerra CE, LaMonte SJ, et al. Colorectal cancer screening for average-risk adults: 2018 guideline update from the American Cancer Society. CA Cancer J Clin. 2018 Jul;68(4): 250-81.

6 Vuik FE, Nieuwenburg SA, Bardou M, Lansdorp-Vogelaar I, Dinis-Ribeiro M, Bento MJ, et al. Increasing incidence of colorectal cancer in young adults in Europe over the last 25 years. Gut. 2019 Oct;68(10):1820-6.

7 Peterse EF, Meester RG, Siegel RL, Chen JC, Dwyer A, Ahnen DJ, et al. The impact of the rising colorectal cancer incidence in young adults on the optimal age to start screening: microsimulation analysis I to inform the American Cancer Society colorectal cancer screening guideline. Cancer. 2018 Jul;124(14): 2964-73.
8 Nogueira RA. Programa Nacional para as Doenças Oncológicas: o despacho $n .^{\circ}$ 8254/2017, de 21 de setembro, do Secretário de Estado Adjunto e da Saúde, merece mais atenção e representa um primeiro passo para a orientação de soluções. Rev Port Clin Geral. 2018;34(2):104-9.

9 Husereau D, Drummond M, Petrou S, Carswell C, Moher D, Greenberg D, et al. Consolidated Health Economic Evaluation Reporting Standards (CHEERS) explanation and elaboration: a report of the ISPOR Health Economic Evaluation Publication Guidelines Good Reporting Practices Task Force. Value Health. 2013;16:231-50.

10 Areia M, Fuccio L, Hassan C, Dekker E, DiasPereira A, Dinis-Ribeiro M. Cost-utility analysis of colonoscopy or faecal immunochemical test for population-based organised colorectal cancer screening. United European Gastroenterol J. 2019 Feb;7(1):105-13.

11 Serviço Nacional de Saúde-SNS. Registo Oncológico Nacional (RON). Lisbon; 2020.

12 Instituto Nacional de Estatística (INE), Portugal. Lisbon; 2020.

13 Djalalov S, Rabeneck L, Tomlinson G, Bremner KE, Hilsden R, Hoch JS. A Review and Meta-analysis of Colorectal Cancer Utilities. Med Decis Making. 2014 Aug;34(6):809-18.

14 Ness RM, Holmes AM, Klein R, Dittus R. Utility valuations for outcome states of colorectal cancer. Am J Gastroenterol. 1999 Jun;94(6):1650-7.
15 SNS. Tables of prices charged by the National Health Service (order No. 207/2017). In: Portuguese Ministry of Health, editor. Republic Diary. 2017. pp. 3550-708.

16 Troeung L, Sodhi-Berry N, Martini A, Malacova E, Ee H, O'Leary P, et al. Increasing Incidence of Colorectal Cancer in Adolescents and Young Adults Aged 15-39 Years in Western Australia 1982-2007: Examination of Colonoscopy History. Front Public Health. 2017 Jul;5:179.

17 Deng Y. Rectal Cancer in Asian vs. Western Countries: Why the Variation in Incidence? Curr Treat Options Oncol. 2017 Sep;18(10): 64.

18 Gregor MF, Hotamisligil GS. Inflammatory mechanisms in obesity. Annu Rev Immunol. 2011;29(1):415-45.

19 Wei EK, Giovannucci E, Wu K, Rosner B, Fuchs CS, Willett WC, et al. Comparison of risk factors for colon and rectal cancer. Int J Cancer. 2004 Jan;108(3):433-42.

20 Larsson SC, Wolk A. Obesity and colon and rectal cancer risk: a meta-analysis of prospective studies. Am J Clin Nutr. 2007 Sep;86(3): $556-65$.

21 von Karsa L, Patnick J, Segnan N, Atkin W, Halloran S, Lansdorp-Vogelaar I, et al.; European Colorectal Cancer Screening Guidelines Working Group. European guidelines for quality assurance in colorectal cancer screening and diagnosis: overview and introduction to the full supplement publication. Endoscopy. 2013;45(1):51-9. 